\title{
Post-Graduation Professors and Coordinators with Special Needs: Perceptions about Teaching, and Working during COVID-19 Pandemic
}

\section{Roberta Pires Corrêa ${ }^{1,2,3,4}$, Roberto Rodrigues Ferreira' ${ }^{1,2,3}$, Paulo Roberto Soares Stephens ${ }^{1,2}$,

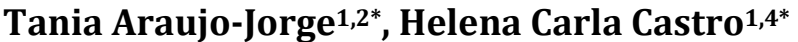

\author{
${ }^{1}$ Programa de Pós-Graduação em Ensino de Biociências e Saúde, Fiocruz, Rio de Janeiro, Brazil \\ ${ }^{2}$ Laboratório de Inovações em Terapias, Ensino e Bioprodutos, Instituto Oswaldo Cruz, Fiocruz, Rio de Janeiro, Brazil \\ ${ }^{3}$ Laboratório de Genômica Funcional e Bioinformática, Instituto Oswaldo Cruz, Fiocruz, Rio de Janeiro, Brazil \\ ${ }^{4}$ PPBI, PGCTIn, CMPDI, LABiEMol, Instituto de Biologia, Universidade Federal Fluminense, Niterói, Brazil \\ Email: hcastro@id.uff.br, taniaaj@ioc.fiocruz.br
}

How to cite this paper: Corrêa, R. P., Ferreira, R. R., Stephens, P. R. S., AraujoJorge, T., \& Castro, H. C. (2021). Post-Graduation Professors and Coordinators with Special Needs: Perceptions about Teaching, and Working during COVID-19 Pandemic. Creative Education, 12, 2594-2608. https://doi.org/10.4236/ce.2021.1211194

Received: August 18, 2021

Accepted: November 19, 2021

Published: November 22, 2021

Copyright $\odot 2021$ by author(s) and Scientific Research Publishing Inc. This work is licensed under the Creative Commons Attribution International License (CC BY 4.0).

http://creativecommons.org/licenses/by/4.0/

(c) (i) Open Access

\begin{abstract}
The challenge of implementing new teaching strategies as well as innovating in the academic environment is a task demanded during this global humanitarian health problem named COVID-19 pandemic. It demanded that most countries adjust their education systems to meet the needs of all students isolated in their houses, requiring even more from professors and coordinators. In this article, we collected and evaluated the perceptions of professors and coordinators of Brazilian postgraduate courses, self-declared with special needs on the impacts of the COVID-19 pandemic in the period 2020/2021. For that purpose, after being approved by the ethical committee, we applied a questionnaire answered by 87 participants with special needs, including professors $(n=14)$ and coordinators $(n=73)$ of post-graduation programs from all five Brazilian regions. Among the 87 participants, there were people with blindness/visual impairment $(\mathrm{n}=35)$, deafness/hearing impairment $(\mathrm{n}=15)$, as well as TDHA/Dyslexia/Autism $(\mathrm{n}=11)$, or physical disability $(\mathrm{n}=8)$, among others. Our work revealed that COVID-19 not only impacted the academic level but also the personal and psychological levels of these professionals with the development of anxiety and depression similar to other professional classes (e.g., health area). Thus, strategies of attending this group from these Brazilian Lato Sensu and Stricto Sensu graduate programs should be planned to help their psychological and mental health and consequently assure their good performance as professors and researchers in the near future.
\end{abstract}




\section{Keywords}

COVID-19, Professor, Coordinator, Concepts, Evaluation

\section{Introduction}

Coronaviruses (CoVs), belonging to the subfamily Coronavirinae, family Coronaviridae and order Nidovirales are capable of infecting vertebrates and humans. CoVs have been detected previously in outbreaks of the severe acute respiratory syndrome (SARS) in 2002/2003, in the Middle East respiratory syndrome (MERS) in 2012, and currently, since December 2019, in the COVID-19 pandemic. The Coronavirus disease 19 is an infective disease caused by SARS-CoV-2, a virus that led to millions of deaths from aggravated pneumonia and named by the Coronaviridae Study Group of the International Committee on Taxonomy of Viruses (ICTV, 2020, McNamara, 2020). This pathogen, which mainly causes enzootic infections in mammals and birds, is capable of infecting cells of the respiratory, gastrointestinal, hepatic, and central nervous systems of humans, reported in recent decades (Chen et al., 2020, Le Chang et al., 2020; Peeri et al., 2021; Telenti et al., 2021).

Among the studies of pandemics manifestations, since the 1990s, nothing like COVID-19 has been described. This pandemic spread rapidly across six continents, attacking communities by surprise and hugely victimizing thousands of people. It presents dilemmas similar to other infectious diseases of global perspective, which need to be explained whereas its complexity still has to be understood (Cheng \& Shan, 2020; Wu et al., 2020).

Pandemics situation has always a historical perspective that reveals the interaction between medicine and society. Global crises caused by contagious diseases such as smallpox, yellow fever, bubonic plague, influenza, cholera and, now COVID-19 became the object of the history of medicine as well as the sociocultural history of these diseases, considering their social, academic, and cultural aspects as well as medicine policies (Akin \& Gözel, 2020; Høiby, 2021). When it comes to the academic context, it involves different actors and actions, and sometimes in multidimensional backgrounds such as those of undergraduate and post-graduation programs (Morin, 2020). This scenario is more intense in the perspective of inclusion, where professionals with special needs had to surpass their individual obstacles to attend to the demand in the middle of a stressful situation such as COVID-19 (National Academies of Sciences, 2019; Leshner, 2020).

The Brazilian post-graduate programs present a hierarchic organization composed with three main groups: 1) the coordination with the coordinator, the vice-coordinator, and the secretary, 2) the researchers that are the professors, and 3) the students. Several studies about the students and professors in graduate or undergraduate levels have been published but the professionals with special needs have been not fully investigated (Medeiros et al., 2020, Aragão et al., 2021, Leal et al., 2021, Patias et al., 2021, Tempski et al., 2021).

The careers of professors with disabilities, including those with a coordination 
role, at different levels of education, especially in graduate studies, revealed the concept of disability not as a limitation or incapacity but as histories of success and resilience. However, to understand disability from its own singularities, it is necessary to recognize which conceptions permeate disability nowadays. This is important in the academic/university space, which could sometimes show disability as a medical condition and not as a biopsychosocial problem (Bronfenbrenner, 1994, Kassar et al., 2019; Pletsch, 2020; Pletsch \& Souza, 2021).

Based on the pandemic scenario and considering the role of understanding the demands of the public with special needs, our purpose here was to analyze the COVID-19 impacts, during the pandemic period of 2020-2021, on the academic, personal, and psychological aspects of Brazilian post-graduation professors and coordinators that have special needs.

\section{Methods}

\subsection{Ethics Committee}

This research is a qualitative-quantitative investigation approved by the Research Ethics Committee of the Instituto Oswaldo Cruz CEP FIOCRUZ/IOC under the CAAE number: 34985420.0.0000.5248, and all respondents have signed the informed consent form before participating.

\subsection{Information Collection Procedures}

Given the scenario of social distancing of COVID-19 pandemic, it was necessary to use research tools that reached participants in an easy and fast way. Thus, we used Google Forms that is a free online tool from Google platform and allows us to create multiple choices, open or scale-format questionnaires. The link to the questionnaire can be sent to the participants via email and/or through WhatsApp and any other social media (Monteiro \& Santos, 2019; Mota, 2019). Previously to spreading the link, the questionnaire was remotely validated by a focus group with the mediation of a moderator. All professionals (coordinators and professors) received an invitation to participate via social networks and/or by email from 10/28/2020 to 03/15/2021.

\subsection{Participants}

The 87 participants were selected to have their answers analyzed based on their self-declared special needs (14 coordinators and 73 professors) among 1278 respondents in which 1191 have no self-declared disability and/or special needs. Bone diseases, cardiopathies, and metabolic diseases such as diabetes were also declared as special needs by these 87 participants $(n=18 ; 20 \%)$. We did not exclude these individuals since according to them these diseases cause some type of limitation to their life (professional and/or personal), and we decided that this concept should not be ignored.

The rate of about 1:5 (coordinator:professor) cannot be discussed in this article to guarantee the representativeness of results since Brazil did not make the 
census planned to be made on 2020, only have data from eleven years ago. Therefore, we have no data about people with special needs related to pos-graduation programs to compare this specific rate. In addition, the Brazilian pos-graduation programs can be as small as being composed with 8 professors or as large as having 300 of them.

\subsection{Data Analysis}

We analyzed the participants' answers from the Excel data automatically generated in the Google Form Platform. During the analysis, the percentage of participants who selected each answer was calculated and qualitative analysis was performed as described by Palma et al. 2018.

\section{Results and Discussion}

Individuals and social groups in different historical times and geographical spaces have produced their own ways of defining meanings. It reflects not only changing medical knowledge and technologies, but also broader influences such as ethnicity and class obligations, state policies and responsibilities, religious beliefs, gender, nationality, also including in this scenario the special needs perspective (Sevalho, 1997; Souza, 2005). Although COVID-19 is an immediate biological event, it is also a social event, becoming a potential occasion for the development and legitimation of public policies and strategies to help different groups including people with special needs. This requires us to know the different perspectives that affect this public with special needs to help them to surpass any obstacle that may be imposed after this pandemic situation (Souza, 2020; Tilghman et al., 2021).

Among the 87 respondents with self-declared special needs that participated in our study, most of them were people with blindness/visual impairment $(\mathrm{n}=$ $35 ; 40 \%)$ or deafness/hearing impairment $(\mathrm{n}=15 ; 17 \%)$. Unfortunately, Brazil should have done the collection of demographic data the last year but because of the pandemic situation, this was not performed. However, our result agrees with the demographic data about people with special needs in the Brazilian population currently available in which blind and deaf are among the largest groups with special needs in Brazil (IBGE, 2010). We also have identified Attention-Deficit/Hyperactivity Disorder (ADHD), Dyslexia, and Autism ( $\mathrm{n}=11$; $12 \%)$, physical disability $(\mathrm{n}=8 ; 9 \%)$ and other diseases metabolic diseases pointed as special needs $(n=18 ; 20 \%$, see Methods). Most of them $(n=60 ; 68 \%)$ answered the questionnaire in 2020 and the group was composed mainly by white people $(\mathrm{n}=66 ; 75 \%), 41-60$ years $(\mathrm{n}=43 ; 49 \%)$, with a salary over $\mathrm{R} \$ 7800.00(\mathrm{n}=76 ; 87 \%)$. This agrees with studies that report the higher accessibility of white middle-age people to higher degree jobs and salaries in good places such as universities (Li \& Koedel, 2017; Carnevale et al., 2019; Lawler, 2020). The group has a similar distribution between males $(n=43 ; 49 \%)$ and females $(n=46 ; 52 \%)$, which lived with $1-3$ people at home $(n=77 ; 88 \%)$ at the time of the research. When it comes to people without special needs, this distri- 
bution varies, especially in the technological area, where men are more represented than women in the reported evaluations (Garcia, 2014).

Interestingly, the regional distribution of the 87 participants followed the Brazilian Master courses distribution, spread mainly over Southeast ( $n=38 ; 43 \%$ ), South $(\mathrm{n}=23 ; 26 \%)$ and Northeast $(\mathrm{n}=16 ; 18 \%)$ and lesser at Midwest $(\mathrm{n}=6$; $6 \%)$ and North $(\mathrm{n}=4 ; 4 \%)$ (Figure 1$)$.

As expected, almost $100 \%$ had a doctorate degree $(n=86 ; 98 \%)$ since this degree level is an important prerequisite demanded to be a professor and/or a coordinator in Brazilian post-graduate programs. The requirement is mandatory at Brazilian public universities which were the majority of the workplace of this group $(85 ; 97 \%)$ and even more for those in the coordinator position. Despite several reports of some authors about the difficulties of people with special needs to achieve the higher education, it is still possible to verify that some people with disabilities manage to circumvent this "broken" system, by completing higher education, reaching Stricto sensu postgraduate studies, and getting their degrees at this level (Orlando \& Caiado, 2014).

In our evaluated group, $48 \%$ had a post-doc degree $(n=42)$ and $28 \%$ had a public fellowship as outstanding researchers $(n=25)$. According to some authors,

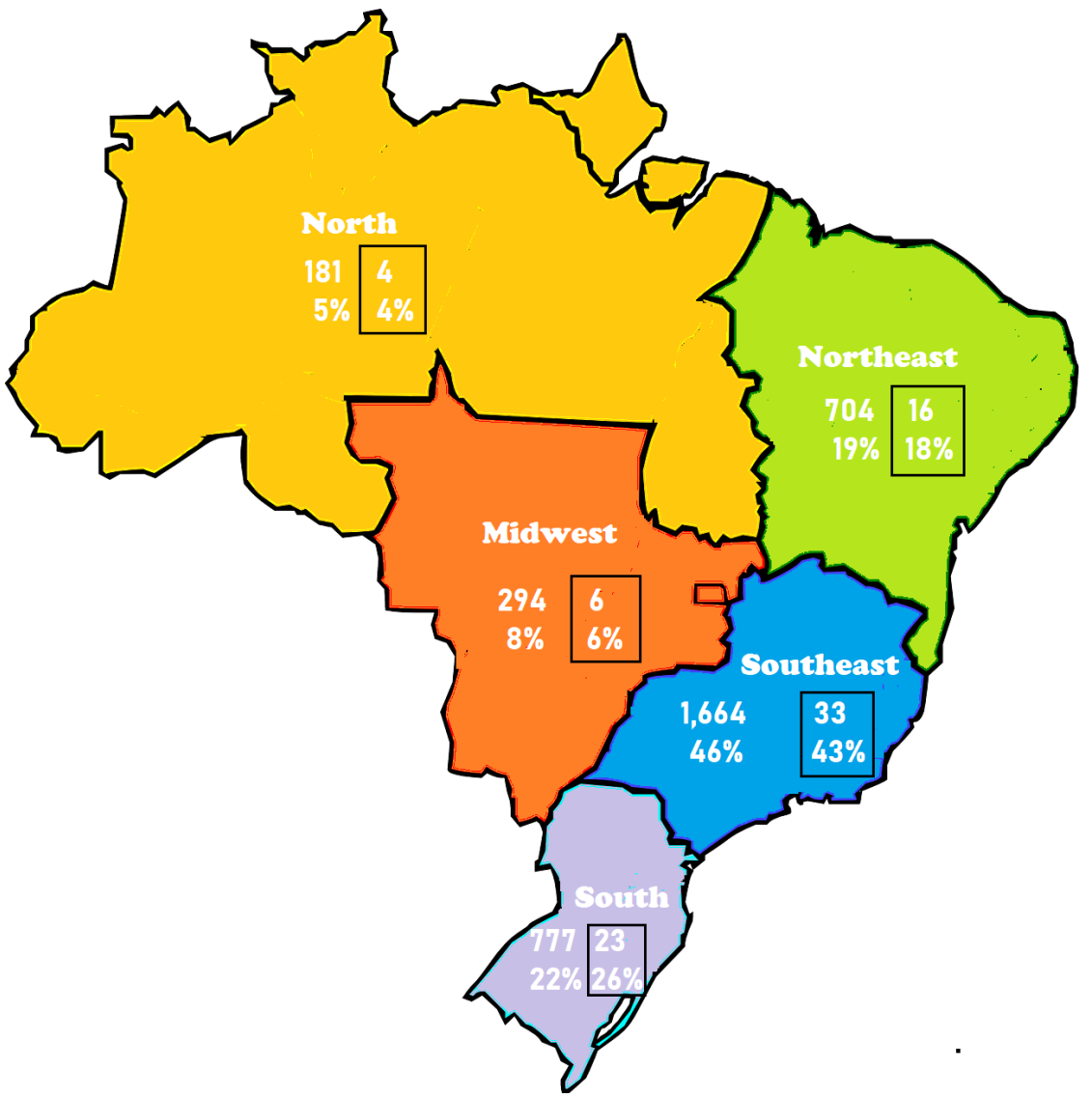

Figure 1. Comparison of the regional distribution of the 87 self-declared special needs participants (boxed) with the Brazilian master courses distribution in 2014. These regional data to construct the map were obtained from the Center for Management and Strategic Studies (CGEE, 2016). 
this profile is not so common as these researchers should have achieved the scientific knowledge throughout their schooling process, despite the restrictions they experienced for social/academic participation. Cases such as those involving the deaf community are really difficult as they depend on high-quality interpreters and signs for academic terms that do not currently exist in several Countries Sign Language, including Brazil where BLS is a young language that is still growing and improving (Capelli et al., 2020, Silva et al., 2020, Castro et al., 2020).

During the pandemic, most of the group kept remote/online activities $(\mathrm{n}=78$; $89 \%)$ and dedicated at least $40 \mathrm{~h}$ weekly to their academic activities $(\mathrm{n}=73$; $83 \%)$. The respondents felt workload increase during this period $(n=60 ; 68 \%)$ and according to their answers, a high number of their post-graduate students had to make changes into their research projects ( $n=79 ; 90 \%)$, sometimes even replan from scratch all their research work $(n=42 ; 49 \%)$.

All respondents had internet access and maintained all their teaching activities, being also involved on advising the defense of dissertations and thesis of their students during their research activities $(n=87 ; 100 \%)$. Among the 87 participants, 78 (90\%) did not have to share their computer with anyone in the family but 48 (55\%) had internet that was not fully serviceable to their academic activity requirements. Different from expected, only 5\% pointed this internet situation negatively to their performance. Lately, with the intensive use of the internet for teaching purposes, complains about the performance and quality of internet access have been reported in different academic areas (CGI.br, 2017; Godoi et al, 2020). Some authors tried to understand innovative pedagogies and the factors that affect the performance of learners. This may help us in a near future, especially after this pandemic period, in order to organize and orientate the education of the next generation with help of these professors (Haniya \& $\mathrm{Pa}$ quette, 2020; Hill \& France, 2020).

Before the pandemic, only 5 (5\%) respondents had not used online tools whereas 18 (20\%) only used them for personal purposes. Importantly, only 17 (19\%) were trained by the institution to use the online teaching tools and felt autonomous to work with, whereas 28 (32\%) were also trained but still need help and 19 were totally self-trained. Most of them $(n=70 ; 80 \%)$ were at least moderately satisfied with their own performance and intend to use online resources after pandemic $(n=79 ; 90 \%)$. This perception is aligned to the current literature that discussed that on-line tools came to stay in the education of future generations pointing to the pandemic as a turning point situation with huge investments of big corporations (Grossi et al., 2021; Wayne et al., 2020, Țurcanu et al., 2020, Mola, 2020).

Regarding to COVID-19 infection, 7 (8\%) respondents got infected (2 at the time of collection) and $14(16 \%)$ did not know at all. The group had a significant COVID's risk group $(\mathrm{n}=30 ; 34 \%)$ with contaminated relatives $(\mathrm{n}=7 ; 8 \%)$ or with family members with symptoms but without testing $(n=6 ; 6 \%)$. Consider- 
ing their age (41 - 60 years; $\mathrm{n}=43 ; 49 \%)$, this risk group accords to reports from World Health Organization (WHO) and Centers for Disease Control and Prevention (CDC) that established these ages as presenting higher risk to get infected and aggravate to higher death risk situation (CDC, 2019; Garg et al., 2020; Yao et al., 2020; Luo et al., 2020, Ripoll et al., 2021).

According to our analysis, a high number of the respondents $(\mathrm{n}=77 ; 88 \%)$ were affected by COVID-19, at least partially (levels 3-5 in 5 points Likert scale). Several declared needing emotional support and sought help from family members and friends $(\mathrm{n}=53 ; 60 \%)$. Probably, part of this need is related to taking care of children and the elderly. Since 32 (36\%) reported it, with 10 (11\%) being the main responsible of these activities.

It is important to notice that, despite their high level of knowledge, those who felt the need for emotional support did not look for help in clinics with doctors, psychiatrists, and/or psychologists. This is similar to what was reported in the literature, where people with knowledge that recognize the importance of the infective component of this pandemic situation but ignore its psychological aspects, including people from health areas (Correa et al., 2021). In fact, they should identify the assessment of these psychological aspects as essential for a full health state (Perez et al., 2019; Gulliver et al., 2019; Gruber et al., 2020; Ornell et al., 2020; Lima, 2020; Santos, 2020). Similar to other professionals, many of these professors and coordinators developed anxiety and/or depression $(\mathrm{n}=$ 38 ; $43 \%)$, but just a few had support from their institutions when they needed it ( $n=5 ; 5 \%)$ (Corrêa et al., 2021).

The number of answers to the question about difficulties that emerged during the pandemic ( $n=68 ; 78 \%$ ) allowed us to classify them in groups that debate the same topic. One answer could be classified in more than one group if approaching several simultaneously (Figure 2). Among the classes of difficulties that appeared during pandemics with the highest level of response were Teaching performance issues, generally regarding to the conditions of internet access and form of evaluation assessment of students performance; Lack of face-to-face contact, that apparently decreased the participation of the students and compromised their interest and performance; and Work overload including mixing home activities with home office besides all professional demands that significantly increased during pandemics, according to them.

The analysis using phrases selection showed different issues regarding the pandemic situation revealed by the analyzed group when the focus was psychological and mental perspectives. This agrees with some authors predictions regarding professional education and COVID-19 (Sahu, 2020). Among these problems we detected concentrating issues (I had difficulty concentrating $=51$; $58 \%$ ), demotivation ( $\mathrm{n}=47 ; 54 \%)$, difficulty sleeping $(\mathrm{n}=45 ; 51 \%)$, and development of anxiety attacks (I had anxiety attacks $=43 ; 49 \%$ ) (Figure 3 ).

Many of the professors and coordinators did not feel safe when leaving home ( $n=40 ; 45 \%$ ), and one among four needed to seek help ( $\mathrm{I}$ had the need to seek 


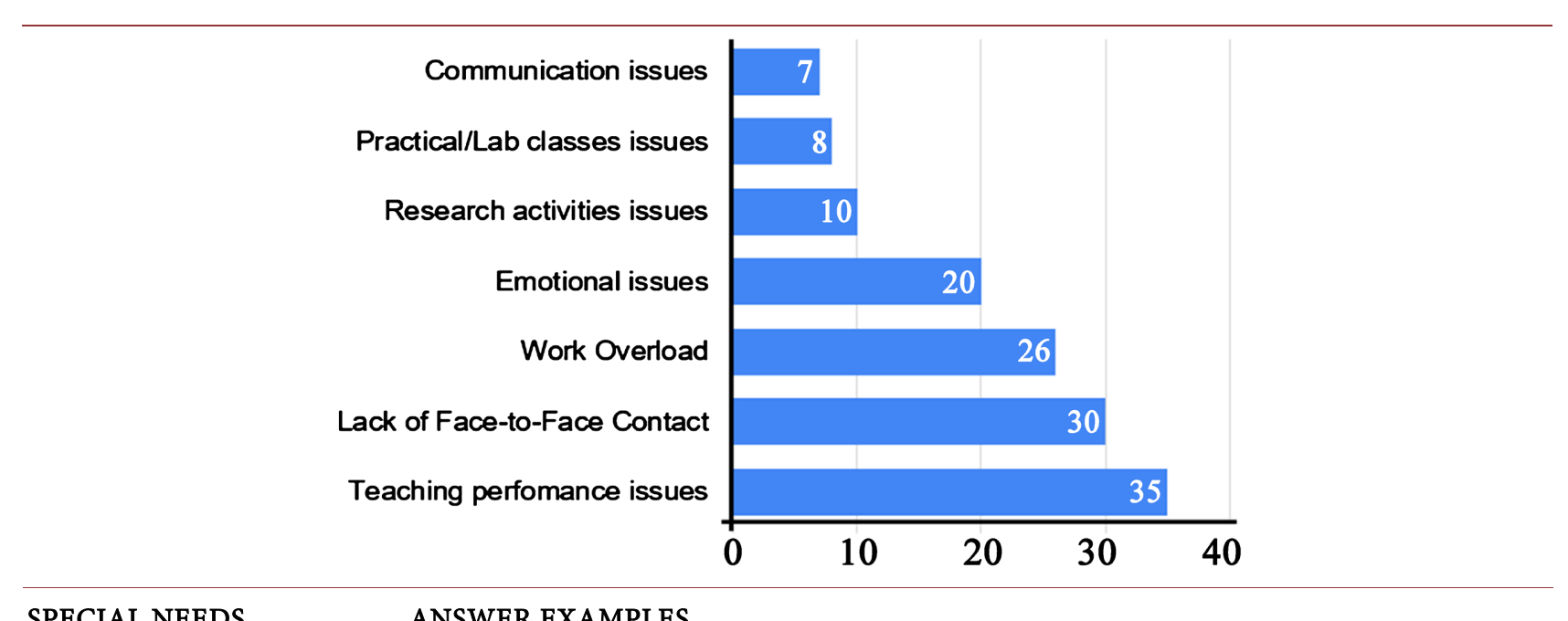

\section{SPECIAL NEEDS}

Visual

impairment

\section{ANSWER EXAMPLES}

Difficulty in organizing graduate courses and activities remotely

The combination of all times and obligations of a personal, professional, family nature. The distancing made all activities difficult, although it allowed distant people to participate in some activities.

Having to learn to use online work tools. Readjust the teaching plan for remote activities (exclude texts from books because there is no PDF available/legal). Record lessons. Make Lives. Working from home ALL THE TIME. The invasion of the domestic routine by work activities at all hours of the day and EVERY DAY, even on weekends. Not being able to leave the house. Having to isolate yourself from co-workers and students. Not being able to go to the library. Impossibility to participate in person in newsstands and congresses. Being prevented from traveling, from meeting relatives, friends and loved ones.

Excessive remote activities with physical and psychological effects

We are being threatened by the virus and also by political conduct. The feeling of threat predates the virus for this reason. Our fragility as professors is very great and greatly influences our mental state and performance. It also influences our online activities.

Very difficult to guide, even more so without contact with the samples being studied.

Hearing deficiency

Difficulty in communicating and transmitting program content.

Difficulty in conducting laboratory experiments.

Communication difficulty.

Difficulty in adapting to the virtual world.

Difficulty in adapting teaching material.

Teaching a screen (no student interaction), working $100 \%$ of the time looking at a computer screen.

Attention-Deficit/Hyperactivity Impossibility of face-to-face meetings with students and colleagues; impossibility of conducting Disorder (ADHD)

in-person research activities; complete dependence on digital media to get the job done and communicate.

Figure 2. Comparison of the difficulties emerged during the COVID-19 according to the special needs group answers ( $\mathrm{n}=68$; 78\%). They were classified into seven groups: Communication issues, Practical Lab classes issues, Research Activities Issues, Emotional Issues, Wok Overload, Lack of face-to-face Contact, Teaching performance Issues. They were classified in more than one group when they fit in. 


\section{Professors and Coordinators}

I had difficulty concentrating

I felt unmotivated

I had difficulty sleeping

I had anxiety attacks

I don't feel safe when leaving the house

I have the need to seek for psychological help

I used self-medication (anxiolytics and/or

antidepressants)

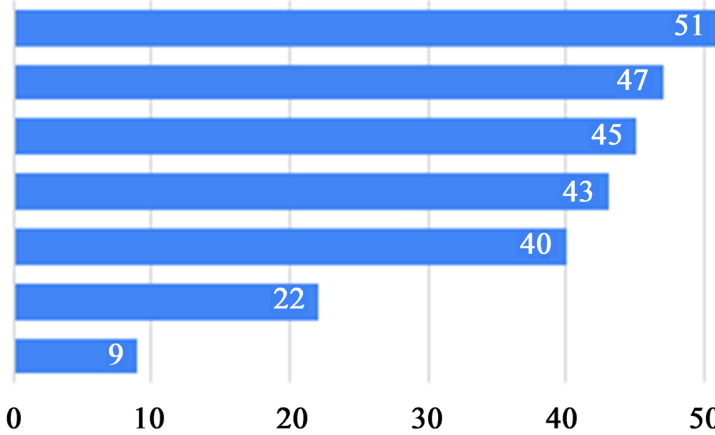

Students situation according to Professors and Coordinators opinions

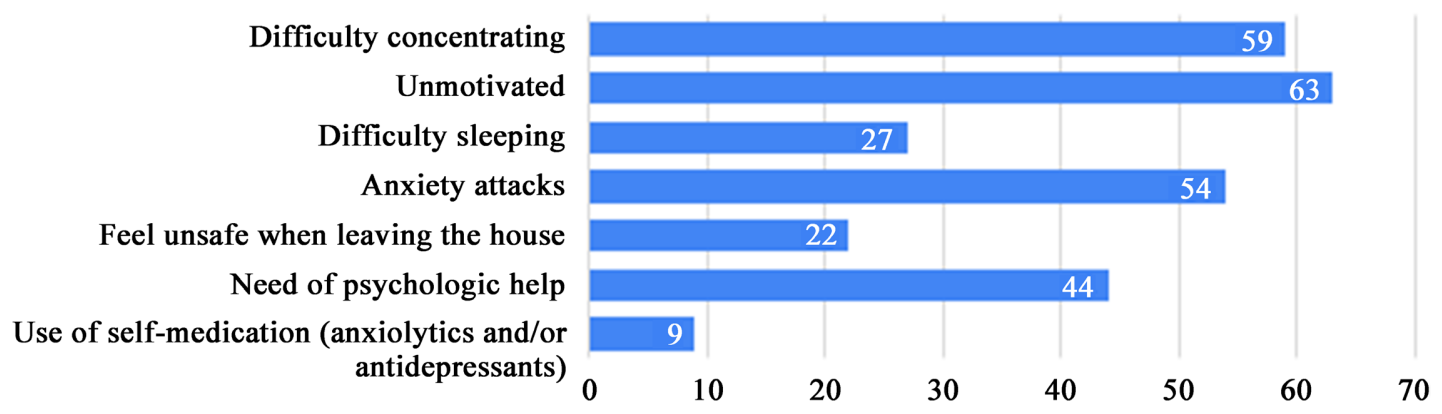

Figure 3. Comparison of the psychological and mental issues regarding the pandemic situation based on the perceptions of professors and coordinators with special needs from post-graduation programs of Brazil $(n=87)$ about them (up) and their students (down).

psychological help $=22 ; 25 \%)$, using sometimes the dangerous strategy of self-medication (I took self-medication, anxiolytics and/or antidepressants $=9$; 10\%). Authors such as Weiss and Li 2020 described strategies for protecting the safeness of leading professionals of the health areas, including mentally and psychologically, by proposing program directors that focus on myriad threats to prioritize their well-being. This kind of program may be useful to professors and coordinators that now are being requested to return to their professional activities at the same time when SAR-COV-2 mutant strains such as Delta are still a threat on the way.

Importantly, when it comes to their perceptions about their students, they think that the biggest problem would be the demotivation with the whole situation, followed by difficulty concentrating and the development of anxiety attacks. These perceptions agree with reports from Collado-Boira et al., 2020 that pointed negative feelings including uncertainty, nervousness, and fear described by 67 final-year nursing and medical students, and Pritchard et al., 2021 that discussed suicide deaths and COVID-19 pandemic among the young people as a call for Children and Psychiatry Services attention. Interestingly, our group of professors and coordinators think that their students have a higher need for psychological help than themselves, which leads to the concern about them not getting proper help, ignoring their own situation, and worsening this scenario (Figure 3 ). 


\section{Conclusion}

Health and disease became themes of interest for scientists of different areas, from biology to social sciences. The dialogue between humans and these sciences broadened the focus onto these subjects. This allows the health-disease process to be studied not only as a problem in itself, but also as a tool to discuss important conceptions that involve from social values to institutional and/or health practices of a society. Our analysis revealed that the group of professors and coordinators with special needs that participate in this study is not that different from other professionals without any special needs, from education or health areas. Similarly, we identified stressful situations, including the development of anxiety and depression. There was also a high-risk group that struggles with psychological and mental issues, besides difficulties regarding their teaching performance and problems involving communication, research activities, and emotional aspects, among others.

It is important to consider that we did not profoundly evaluate each special need per se. Specific analyses of these special needs could reveal an interesting perspective, especially if these professionals were born blind or deaf instead of becoming blind, deaf, or with a hearing or visual impairment after a certain age. The people that developed special needs in elderliness did not experience the same struggle as the other ones during their academic life. These individuals may be well-adapted when it comes to changes imposed by situations such as COVID-19, since they know the world before the deficiency.

Overall, our study is of importance as it reinforced two important points including: a) the need of strategies for attending this group psychologically and mentally in the near future to avoid the negative effects of this pandemic, and b) the necessity of more studies focusing on knowing deeper this public to better meet their needs. Considering the absence of studies regarding the group of students with special needs, this article also highlights the necessity of studies approaching them as well since the negative pressure during this worry pandemic situation called COVID-19 is constantly pointed by our participants.

\section{Acknowledgements}

The authors thank CAPES, CNPq (313011/2018-4, 309703/2019-0), FAPERJ (E-26/210.844/2019; 201.983/2020, and E-26/201.146/2021; 26/203.000/2017), UFF-PROPPi and UFF-Agir for the fellowships and financial support.

\section{Conflicts of Interest}

The authors declare no conflicts of interest regarding the publication of this paper.

\section{References}

Akin, L., \& Gözel, M. G. (2020). Understanding Dynamics of Pandemics. Turkish Journal of Medical Sciences, 50, 515-519. https://doi.org/10.3906/sag-2004-133 
Aragão, M., Gomes, F., Pinho Maia Paixão-de-Melo, L., \& Corona, S. (2021). Brazilian Dental Students and COVID-19: A Survey on Knowledge and Perceptions. European Journal of Dental Education: Official Journal of the Association for Dental Education in Europe. https://doi.org/10.1111/eje.12676

Bronfenbrenner, U. (1994). A ecologia do desenvolvimento humano (M.A.V. Veronesi, Trad). Porto Alegre: Artes Médicas. (Trabalho original publicado em 1994)

Capelli, J. C. S., Di Blasi, F., \&Dutra, F. B. S. (2020). Professors' Perception of the Entry of a Deaf Student into a University Campus. Revista Brasileira de Educação Especial, 26, 85-108. https://doi.org/10.1590/s1413-65382620000100006

Carnevale, A. P., Strohl, J., Gulish, A., Van Der Werf, M., \& Campbell, K. P. (2019). The Uneven Race for Good Jobs: How Whites Outperformed Gains in Education and Good Jobs Compared to Blacks and Latinos (p. 44). University of Georgetown. ERIC Number: ED600048. https://files.eric.ed.gov/fulltext/ED600048.pdf

Castro, H. C., Ramos, A. S. L., Amorim, G., \& Ratcliffe, N. A. (2020). COVID-19: Don't Forget Deaf People. Nature, 579, 343. https://doi.org/10.1038/d41586-020-00782-2

Centers for Disease Control and Prevention CDC (2019). People Who Are at Higher Risk for Severe Illness. Coronavirus Disease 2019.

https://www.cdc.gov/coronavirus/2019-ncov/need-extra-precautions/people-with-medi cal-conditions.html?CDC AA refVal=https\%3A\%2F\%2Fwww.cdc.gov\%2Fcoronaviru s\%2F2019-ncov\%2Fneed-extra-precautions\%2Fgroups-at-higher-risk.html

Centro de gestão e estudos estratégicos CGEE (2016). Mestres e doutores-Estudos de monografia da base técnico-científica brasileira (p. 348). Brasília. https://www.cgee.org.br/web/rhcti/mestres-e-doutores-2015

Chang, L., Yan, Y., \& Wang, L. (2020). Coronavirus Disease 2019: Coronaviruses and Blood Safety. Transfusion Medicine Reviews, 34, 75-80. https://doi.org/10.1016/j.tmrv.2020.02.003

Chen, Y., Liu, Q., \& Guo, D. (2020) Emerging Coronaviruses: Genome Structure, Replication, and Pathogenesis. Journal of Medical Virology, 92, 418-423. https://doi.org/10.1002/jmv.25681

Cheng, Z. J., \& Shan, J. (2020). 2019 Novel Coronavirus: Where We Are and What We Know. Infection, 48, 155-163. https://doi.org/10.1007/s15010-020-01401-y

Collado-Boira, E. et al. (2020). “The COVID-19 Outbreak"-An Empirical Phenomenological Study on Perceptions and Psychosocial Considerations Surrounding the Immediate Incorporation of Final-Year Spanish Nursing and Medical Students into the Health System. Nurse Education Today, 92, 1-5.

https://doi.org/10.1016/j.nedt.2020.104504

Comitê Gestor da Internet no Brasil CGI.br (2017). Cultura e tecnologias no Brasil: Um estudo sobre as práticas culturais da população e o uso das tecnologias de informação e comunicação. CGI.br. https://cetic.br/pt/publicacao/cultura-e-tecnologias-no-brasil/

Corrêa, R., Castro, H., Quaresma, B., Stephens, P., Araujo-Jorge, T., \& Ferreira, R. (2021). Perceptions and Feelings of Brazilian Health Care Professionals Regarding the Effects of COVID-19: Cross-Sectional Web-Based Survey. JMIR Formativie Research, 5, e28088. https://formative.jmir.org/2021/10/e28088 https://doi.org/10.2196/28088

García, V. G. (2014). Panorama da inclusão das pessoas com deficiência no mercado de trabalho no Brasil. Trabalho, Educação e Saúde, 12, 165-187. https://doi.org/10.1590/S1981-77462014000100010

Garg, S., Kim, L., Whitaker, M., O’Halloran, A., Cummings, C., Holstein, R., Prill, M., Chai, S. J., Kirley, P. D., Alden, N. B., Kawasaki, B., Yousey-Hindes, K., Niccolai, L., 
Anderson, E. J., Openo, K. P., Weigel, A., Monroe, M. L., Ryan, P., Henderson, J., Kim, S., Fry, A. et al. (2020). Hospitalization Rates and Characteristics of Patients Hospitalized with Laboratory-Confirmed Coronavirus Disease 2019. MMWR Morbidity and Mortality Weekly Report, 69, 458-464. https://doi.org/10.15585/mmwr.mm6915e3

Godoi, M. et al.(2020). O ensino remoto durante a pandemia de covid-19: Desafios, aprendizagens e expectativas dos professores universitários de educação física. $R e$ search, Society and Development, 9, 1-19. https://doi.org/10.33448/rsd-v9i10.8734

Grossi, M. G. R. (2021). Usar tecnologias digitais nas aulas remotas durante a pandemia da COVID-19? Sim, mas quais e como usar? Olhar De Professor, 24, 1-12. https://doi.org/10.5212/OlharProfr.v.24.15879.059

Gruber, J., Van Bavel, J. J., Cunningham, W. A., Leah, H., Somerville, L. H., \& Lewis, N. A. (2020). A academia precisa de uma verificação da realidade: $A$ vida não voltou ao normal. Letters to Young Scientists.

https://www.sciencemag.org/careers/2020/08/academia-needs-reality-check-life-not-ba ck-normal

Gulliver, A., Farrer, L., Bennett, K., \& Griffiths, K. (2019). Alfabetização de funcionários da universidade em saúde mental, estigma e sua experiência de alunos com problemas de saúde mental. Journal of Further and Higher Education, 43, 434-442.

Haniya, S., \& Paquette, L. (2020). Understanding Learner Participation at Scale: How and Why. E-Learning and Digital Media, 17, 236-252. https://doi.org/10.1177/2042753019900963

Hill, J., \& France, D. (2020). Innovative Pedagogies. In International Encyclopedia of Human Geography (2nd ed., pp. 331-339). Elsevier. https://doi.org/10.1016/B978-0-08-102295-5.10657-2

Høiby, N. (2021). Pandemics: Past, Present, Future: That Is like Choosing between Cholera and Plague. APMIS: Acta Pathologica, Microbiologica, et Immunologica Scandinavica, 129, 352-371. https://doi.org/10.1111/apm.13098

ICTV-Coronaviridae Study Group of the International Committee on Taxonomy of Viruses (2020). The Species Severe Acute Respiratory Syndrome-Related Coronavirus: Classifying 2019-nCoV and Naming It SARS-CoV-2. Nature Microbiology, 5, 536-544. https://doi.org/10.1038/s41564-020-0695-Z

Instituto Brasileiro de Geografia e Estatística IBGE (2010). Censo Demográfico 2010. População residente por tipo de deficiência, segundo a situação de domicílio, o sexo e os grupos de idade. Características gerais da população.

https://sidra.ibge.gov.br/tabela/3425

Kassar, de Carvalho Magalhães, M., \& Andressa Santos e Oliveira, R. (2019). Regina Tereza Cestari de Embates e disputas na política nacional de Educação Especial brasileira 11: Partes do material empírico foram anteriormente apresentadas no VI Congresso Ibero-Americano/IX Congresso Luso-Brasileiro de Política e Administração da Educação, em Lleida (ES) e no XIV Encontro de Pesquisa em Educação da Região Centro-Oeste, em Cáceres (MT-BR), no ano de 2018. Educação e Pesquisa, 45, e217170. https://doi.org/10.1590/s1678-4634201945217170

Lawler, A. (2000). No More Silent: “Model Minority” Mobilizes. Science, 290, 1072-1077. https://science.sciencemag.org/content/290/5494/1072 https://doi.org/10.1126/science.290.5494.1072

Leal Filho, W., Wall, T., Rayman-Bacchus, L., Mifsud, M., Pritchard, D. J., Lovren, V. O., Farinha, C., Petrovic, D. S., \& Balogun, A. L. (2021). Impacts of COVID-19 and Social Isolation on Academic Staff and Students at Universities: A Cross-Sectional Study. BMC Public Health, 21, 1213. https://doi.org/10.1186/s12889-021-11040-z 
Leshner, A. I. (2020). Restart to Science with More Force after COVID-19. Science, 369, 261-262. https://doi.org/10.1126/science.abd5780

Li, D., \& Koedel, C. (2017). Representation and Wage Differences by Racial Ethnicity and Gender in Selective Universities. Educational Researcher, 46, 12. https://doi.org/10.3102/0013189X17726535

Lima, R. C. (2020). Distanciamento e isolamento sociais pela Covid-19 no Brasil: Impactos na saúde mental. Physis: Revista de Saúde Coletiva, 30, e300214. https://doi.org/10.1590/s0103-73312020300214

Luo, H., Liu, S., Wang, Y., Phillips-Howard, P. A., Ju, S., Yang, Y., \& Wang, D. (2020). Age Differences in Clinical Features and Outcomes in Patients with COVID-19, Jiangsu, China: A Retrospective, Multicentre Cohort Study. BMJ Open, 10, e039887. https://doi.org/10.1136/bmjopen-2020-039887

McNamara, A. (2020). CDC Confirms First Case of Coronavirus in the United States. https://www.cbsnews.com/news/coronavirus-centers-for-disease-control-first-case-uni ted-states

Medeiros, R. A., Vieira, D. L., Silva, E., Rezende, L., Santos, R., \& Tabata, L. F. (2020). Prevalence of Symptoms of Temporomandibular Disorders, Oral Behaviors, Anxiety, and Depression in Dentistry Students during the Period of Social Isolation Due to COVID-19. Journal of Applied Oral Science: Revista FOB, 28, e20200445. https://doi.org/10.1590/1678-7757-2020-0445

Mola, R. (2020). Microsoft, Google, and Zoom Are Trying to Keep Up with Demand for Their Now Free Work-from-Home Software. Vox. https://www.vox.com/recode/2020/3/11/21173449/microsoft-google-zoom-slack-increa sed-demand-free-work-from-home-software

Monteiro, R. L. S., \& Santos, D. S. (2019). A utilização da ferramenta google forms como instrumento de avaliação do ensino na escola superior de guerra. Revista Carioca de Ciência, Tecnologia e Educação, 4, 28-38.

https://recite.unicarioca.edu.br/rccte/index.php/rccte/article/view/72/106 https://doi.org/10.17648/2596-058X-recite-v4n2-3

Morin, K. (2020). Nursing Education after COVID-19: Same or Different? Journal of Clinical Nursing, 29, 17-18. https://doi.org/10.1111/jocn.15322

Mota, J. S. (2019). Utilização do google forms na pesquisa acadêmica. Revista Humanidades e Inovação, 6, 372-380. https://revista.unitins.br/index.php/humanidadeseinovacao/article/view/1106

National Academies of Sciences, Engineering and Medicine (2019). The Science of Effective Mentorship in STEMM. National Academies Press.

Orlando, R. M., \& Caiado, K. R. M. (2014). Professores universitários com deficiência: Trajetória escolar e conquista profissional. Educação \& Realidade, Porto Alegre, 39, 811-830. https://doi.org/10.1590/S2175-62362014000300010 https://www.scielo.br/j/edreal/a/MHSVpRYK6KBztHCpJjk9v7N/?format=pdf\&lang=p t

Ornell, F., Schuch, J. B., Sordi, A. O., \& Kessler. F. H. P. (2020). Pandemia De Medo E Covid-19: Impacto Na Saúde Mental E possíveis estratégias. Debates Em Psiquiatria, 10, 12-16. https://doi.org/10.25118/2236-918X-10-2-2

Palma, M. L. M., Santana, A. C., Alves, G. H. V. S., Merçon, T., \& Castro, H. C. (2018). Nursing and Biochemistry: An Evaluation Strategy Using a Basic Discipline to Present to Freshman Students Their Future Professional Environment. Creative Education, 9, 497-512. https://doi.org/10.4236/ce.2018.93035 
Patias, N. D., Von Hohendorff, J., Cozzer, A. J., Flores, P. A., \& Scorsolini-Comin, F. (2021). Mental Health and Coping Strategies in Undergraduate and Graduate Students during COVID-19 Pandemic. Trends in Psychology, 1-20. https://doi.org/10.1007/s43076-021-00069-Z

Peeri, N. C., Shrestha, N., Rahman, M. S., Zaki, R., Tan, Z., Bibi, S., Baghbanzadeh, M., Aghamohammadi, N., Zhang, W., \& Haque, U. (2020). The SARS, MERS and Novel Coronavirus (COVID-19) Epidemics, the Newest and Biggest Global Health Threats: What Lessons Have We Learned? International Journal of Epidemiology, 49, 717-726. https://doi.org/10.1093/ije/dyaa033

Perez, K. V., Rodrigues, C. M. L., \& Brun, L. G. (2019). Saúde mental no contexto universitário: Desafios e práticas. Trabalho (En)Cena, 4, 357-365. https://doi.org/10.20873/2526-1487V4N2P357

Pletsch, M. D. (2020). O que há de especial na Educação Especial Brasileira? MomentoDiálogos em Educação, 29, 1-15. https://doi.org/10.14295/momento.v29i1.9357

Pletsch, M. D., \& de Souza, F. F. (2021). Educação comum ou especial? Análise das diretrizes políticas de educação especial brasileiras. Revista Ibero-Americana De Estudos Em Educação, 16, 1286-1306. https://doi.org/10.21723/riaee.v16iesp2.15126

Pritchard, C., Silk, A., \& Hansen, L. (2021). COVID-19 Pandemic: Lessons from Peak Years of Influenza \& Suicide Deaths by Age in Ten Western Countries 1979-2016: An Alert for Psychiatry and Children's Services. Open Journal of Psychiatry, 11, 71-79. https://doi.org/10.4236/ojpsych.2021.112007

Ripoll, V., Godino-Ojer, M., \& Calzada, J. (2021). Teaching Chemical Engineering to Biotechnology Students in the Time of COVID-19: Assessment of the Adaptation to Digitalization. Education for Chemical Engineers, 34, 21-32. https://doi.org/10.1016/j.ece.2020.11.001

Sahu, P. (2020). Closure of Universities Due to Coronavirus Disease 2019 (COVID-19): Impact on Education and Mental Health of Students and Academic Staff. Cureus, 12, e7541. https://doi.org/10.7759/cureus.7541

Santos, C. F. (2020). Reflections about the Impact of the SARS-COV-2/COVID-19 Pandemic on Mental Health. Revista brasileira de psiquiatria, São Paulo, 42, 329. https://doi.org/10.1590/1516-4446-2020-0981

Sevalho, G. (1997). Tempos históricos, tempos físicos, tempos epidemiológicos: Prováveis contribuições de Fernand Braudel e Ilya Prigogine ao pensamento epidemiológico. Memórias do Instituto Oswaldo Cruz, 13, 7-36. https://doi.org/10.1590/S0102-311X1997000100002

Silva, A. G., Batista, T., Giraud, F., Giraud, A., Pinto-Silva, F. E., Barral, J., Guimarães, J. N., \& Rumjanek, V. M. (2020). Science Communication for the Deaf in the Pandemic Period: Absences and Pursuit of Information. Jcom-Journal of Science Communication, 19. https://doi.org/10.22323/2.19050205

Souza, C. M. C. de. (2005). As dimensões político-sociais de uma epidemia: A paulicéia desvairada pela gripe espanhola. História, Ciências, Saúde-Manguinhos, 12, 567-573. https://doi.org/10.1590/S0104-59702005000200023

Souza, O. D. (2020). A pandemia de COVID-19 para além das Ciências da Saúde: Reflexões sobre sua determinação social. Ciência \& Saúde Coletiva, 25, 2469-2477. https://doi.org/10.1590/1413-81232020256.1.11532020

Telenti, A., Arvin, A., Corey, L. et al. (2021). Depois da pandemia: Perspectivas sobre a trajetória futura do COVID-19. Nature. https://doi.org/10.1038/s41586-021-03792-w

Tempski, P., Arantes-Costa, F. M., Kobayasi, R., Siqueira, M., Torsani, M. B., Amaro, B., Nascimento, M., Siqueira, S. L., Santos, I. S., \& Martins, M. A. (2021). Medical 
Students' Perceptions and Motivations during the COVID-19 Pandemic. PLoS ONE, 16, e0248627. https://doi.org/10.1371/journal.pone.0248627

Tilghman, S., Alberts, B., Colón-Ramos, D., Dzirasa, K., Kimble, J., \& Varmus, H. (2021). Concrete Steps to Diversify the Scientific Workforce. Science, 372, 133-135.

https://science.sciencemag.org/content/372/6538/133

https://doi.org/10.1126/science.abf9679

Țurcanu, D., Siminiuc, R., \& Bostan, V. (2020). The Impact of the COVID-19 Pandemic on the Use of Digital Technologies in Ensuring the Efficient e-Learning Process at the Technical University of Moldova. Creative Education, 11, 2116-2132.

https://doi.org/10.4236/ce.2020.1110154

Wayne, D. B., Green, M., \& Neilson, E. G. (2020). Medical Education at the Time of COVID-19. Science Advances, 6, eabc7110.

https://advances.sciencemag.org/content/6/31/eabc7110

https://doi.org/10.1126/sciadv.abc7110

Weiss, P., \& Li, S.-T. T. (2020). Leading Change to Address the Needs and Well-Being of Trainees during the COVID-19 Pandemic. Academic Pediatrics, 20, 735-741.

https://doi.org/10.1016/j.acap.2020.06.001

Wu, D., Wu, T., Liu, Q., \& Yang, Z. (2020). The SARS-CoV-2 Outbreak: What We Know. International Journal of Infectious Diseases: IJID, 94, 44-48.

https://doi.org/10.1016/j.ijid.2020.03.004

Yao, Q., Wang, P., Wang, X., Qie, G., Meng, M., Tong, X., Bai, X., Ding, M., Liu, W., Liu, K., \& Chu, Y. (2020). A Retrospective Study of Risk Factors for Severe Acute Respiratory Syndrome Coronavirus 2 Infections in Hospitalized Adult Patients. Polish Archives of Internal Medicine, 130, 390-399. 